\title{
Modelling of environmental impacts from biological treatment of organic municipal waste in EASEWASTE
}

Boldrin, Alessio; Neidel, Trine Lund; Damgaard, Anders; Bhander, Gurbakhash S.; Møller, Jacob; Christensen, Thomas Højlund

Published in:

Waste Management

Link to article, DOI:

10.1016/j.wasman.2010.10.025

Publication date:

2011

Document Version

Peer reviewed version

Link back to DTU Orbit

Citation $(A P A)$ :

Boldrin, A., Neidel, T. L., Damgaard, A., Bhander, G. S., Møller, J., \& Christensen, T. H. (2011). Modelling of environmental impacts from biological treatment of organic municipal waste in EASEWASTE. Waste Management, 31(4), 619-630. https://doi.org/10.1016/j.wasman.2010.10.025

\section{General rights}

Copyright and moral rights for the publications made accessible in the public portal are retained by the authors and/or other copyright owners and it is a condition of accessing publications that users recognise and abide by the legal requirements associated with these rights.

- Users may download and print one copy of any publication from the public portal for the purpose of private study or research.

- You may not further distribute the material or use it for any profit-making activity or commercial gain

- You may freely distribute the URL identifying the publication in the public portal 
Accepted for publication in Waste Management

\title{
Modelling of environmental impacts from biological treatment of organic municipal waste in EASEWASTE
}

Alessio Boldrin ${ }^{1 *}$, Trine Lund Neidel ${ }^{2}$, Anders Damgaard ${ }^{1}$, Gurbakhash S. Bhander ${ }^{1}$, Jacob Møller ${ }^{1}$, Thomas H. Christensen ${ }^{1}$

\author{
${ }^{1}$ Department of Environmental Engineering \\ Technical University of Denmark \\ Kongens Lyngby, Denmark
}

${ }^{2} \mathrm{COWI} A / \mathrm{S}$

Parallelvej 2

Kongens Lyngby, Denmark

"NOTE: this is the author's version of a work that was accepted for publication in Journal of Waste Management. Changes resulting from the publishing process, such as peer review, editing, corrections, structural formatting, and other quality control mechanisms may not be reflected in this document. Minor changes may have been made to this manuscript since it was accepted for publication. A definitive version is published in Waste Management, vol 31, pp 619-630, doi:10.1016/j.wasman.2010.10.025" 


\begin{abstract}
The waste-LCA model EASEWASTE quantifies potential environmental effects from biological treatment of organic waste, based on mass and energy flows, emissions to air, water, soil and groundwater as well as effects from upstream and downstream processes. Default technologies for composting, anaerobic digestion and combinations hereof are available in the model, but the user can change all key parameters in the biological treatment module so that specific local plants and processes can be modelled. EASEWASTE is one of the newest waste LCA models and the biological treatment module was built partly on features of earlier waste-LCA models, but offers additional facilities, more flexibility, transparency and userfriendliness. The paper presents the main features of the module and provides some examples illustrating the capability of the model in environmentally assessing and discriminating the environmental performance of alternative biological treatment technologies in relation to their mass flows, energy consumption, gaseous emissions, biogas recovery and compost/digestate utilization.
\end{abstract}

Keywords: EASEWASTE, biological treatment, LCA, composting, anaerobic digestion. 


\section{Introduction}

Biological treatment is a common option for management of organic municipal solid waste. At present, approximately 2000 composting facilities (Boldrin et al., 2009), 185 anaerobic digestions plants (IEA, 2008) and 180 Mechanical Biological Treatment (MBT) plants (ECN, 2009) treating - or co-treating - organic municipal waste are in operation in Europe.

Biological treatment of organic waste affects the environment in several ways. The type and magnitude of the effects strongly depend on the specific waste system and technology. The actual quantification of potential environmental effects from biological treatment requires knowledge about mass and energy flows, emissions to air, water, soil and groundwater as well as effects from upstream and downstream processes. Life Cycle Assessment (LCA) is a systematic approach and a standardized methodology for reporting and assessing the abovementioned aspects. A complete LCA study is iteratively carried out through four phases: goal and scope definition, life cycle inventory ( $\mathrm{LCl}$ ) analysis, life cycle impact assessment (LCIA) and interpretation (including uncertainty analysis) (ISO, 2006).

The LCA-model EASEWASTE includes a module for biological treatment of organic waste. This module enables the user to quantify the essential environmental effects from a specific biological treatment technology under local conditions, assuming that defined key parameters describing the system are available. The module contains several default datasets based on existing technologies (windrow composting, tunnel composting, anaerobic digestion, combined digestion/compost, home composting), which may be used if no specific data are available. The basic principles of EASEWASTE are described in Kirkeby et al. (2006).

Since EASEWASTE was built on experience generated by previous models, the first part of this paper presents a brief overview of biological treatment modules in dedicated waste LCA models. In the second part, the functionality of the biological treatment in EASEWASTE is described in detail. Finally, data from four case studies will be presented to: 1 ) illustrate the functionality of the model; 2) provide dataset useful for LCA studies on biological treatment of organic waste; 3 ) indicate key issues and relevant parameters regarding LCA modelling of biological treatments; 4) show the capability of the model of discerning different technologies. This paper focuses on the biological treatment technologies. The environmental issues of using the output from biological treatment in terms of compost and digestate is described in another paper by Hansen et al. (2006).

\section{Review of biological treatment modules in existing waste-LCA models}

A number of models for environmental assessment of waste systems include biological treatment of organic waste. However, the approach and level of detail vary between the models influencing the flexibility (possibility of including specific data) and complexity (user friendliness). The following sub-chapters give a short summary of the approaches used, and some of the strength and weaknesses of each model. The described models have been chosen according to the following criteria:

- A complete waste management system can be modelled and biological treatment is one of the available options. This makes it possible to pay attention to various source sorting schemes upstream from the biological treatment.

- Several waste fractions can be handled simultaneously. Each fraction is described with a chemical composition and can be routed to different treatment. This makes it possible to introduce various guidelines for sorting at the source and thereby include differences in organic waste composition. 
- Both anaerobic digestion and composting are included as technological alternatives (an exception is the MSW-DST model which includes only composting; see later).

- Emissions to the environment are distinguished in process- and waste-related emissions. The latter makes it possible to relate emissions to the composition of the waste treated.

An overview of the different features included in the described models is provided in Table 1, while a review of the general technical assumptions is provided by Gentil et al. (2010).

\subsection{The IFEU Project}

The IFUE Project is a German model for environmental assessment of waste systems based on modelling from the software UMBERTO. The model was developed for comparison of different treatment options for urban organic waste, including municipal organic waste, and the quantification of environmental effects from biological treatment is therefore relatively detailed, as described in Vogt et al. (2002).

Anaerobic digestion is defined by "wet one-step mesophilic digestion" and "dry one-step thermophilic digestion". The digested organic waste is separated into a wet and a dry fraction; the wet fraction led to wastewater treatment and the dry fraction stabilized by a composting step. The produced methane is used for electricity - delivered to the grid - and heat - primarily utilized at the biogas plant. Emission of unburned methane from combustion of the gas is quantified and included in the assessment. Detailed mass balances for carbon and nitrogen describe the fate of the two components in the investigated systems. During the anaerobic digestion a fraction of the carbon is transformed into biogas or eventually lost to wastewater. The rest of the carbon is transferred to the composting step, where it is partly lost as emissions to air (e.g. $\mathrm{CO}_{2}$ or $\mathrm{CH}_{4}$ ) or as wastewater. A substantial part of the nitrogen contained in the wet fraction is lost as ammonia. During the composting stage nitrogen may be emitted to air $\left(\mathrm{NH}_{3}, \mathrm{~N}_{2} \mathrm{O}, \mathrm{N}_{2}\right)$ or to wastewater. The remaining nitrogen is found in the treated organic waste.

Treatment of municipal organic waste by composting is defined by an intensive composting step (open or enclosed) followed by a stabilising composting step (open air windrows). The mass balances for carbon and nitrogen for the two composting steps are similar to the ones performed by the stabilizing composting step after anaerobic digestion. For the closed composting process air cleaning by biofilters may be included to reduce emissions.

\subsection{Organic Waste Research: ORWARE}

ORWARE is a Swedish model developed by a cooperation of different research institutes and universities. The model was originally developed for environmental assessment of biodegradable liquid and organic waste (including sludge), but it can also handle treatment of mixed waste. The modelling in ORWARE is done using a modular approach and transfer coefficients are used to define the elemental distribution in each environmental compartment. Transfer coefficients are also used to model the degradation of organic persistent pollutants ( $\mathrm{CHX}, \mathrm{AOX}, \mathrm{PAH}$, Phenols, PCB and dioxins). In ORWARE, available biological treatments for organic waste are anaerobic digestion and composting. Detailed description of biological treatment in ORWARE can be found in Dalemo et al. (1997) and Dalemo (1999).

Anaerobic digestion is exemplified by a continuously stirred tank reactor (CSTR) one-step mesophilic digestion. Four pre-treatments are possible for the incoming waste: hygienisation $\left(70^{\circ} \mathrm{C}\right)$, sterilization $\left(130^{\circ} \mathrm{C}\right)$, maceration, and separation of metal and plastic. The degradation of organic matter is estimated taking into account the degradation potential of the substrate and the retention time in the digester. Degradation is estimated separately for the different 
organic compounds (fat, protein, carbohydrates, etc.). The production of biogas $\left(\mathrm{CO}_{2}+\mathrm{CH}_{4}\right)$ is proportional to the amount of organic matter degraded. Mineralisation of organic nitrogen to ammonium and sulphur to hydrogen sulphide are proportional to the degradation ratio of proteins contained in the waste. The electricity consumption is estimated to be approximately $5 \%$ of the energy contained in the biogas, while the heat consumption is estimated taking into account the surface area of the reactors and the retention times. Utilisation of the biogas is modelled in a separate sub-module, with various options for the energy recovery (engine, boiler, buses, cars and trucks). When the produced biogas is combusted in a stationary engine, the energy recovery efficiency is $30 \%$ for electricity and $60 \%$ for heat.

Three options are available in ORWARE for treatment of municipal organic waste by composting: home-, windrow- and reactor composting. The models are basically the same, the differences are modelled in terms of energy consumption, gas cleaning system and content of heavy metals - i.e. lower concentrations in small systems such as home composting. The model assumes that anaerobic conditions never occurs (i.e. no $\mathrm{CH}_{4}$ emissions) and that all leachate water is recirculated. The gaseous losses of nitrogen are calculated according to the Kirchmann's equation (see Dalemo et al., 1997) and distributed into $\mathrm{N}_{2} \mathrm{O}(2 \%), \mathrm{N}_{2}(2 \%)$, and $\mathrm{NH}_{3}$ (96\%). When used, the gas cleaning system is composed of a condensation unit and biofilter. The removal efficiencies are $90 \%$ for $\mathrm{NH}_{3}$ and $\mathrm{N}_{2} \mathrm{O}$, and $50 \%$ for $\mathrm{CH}_{4}$ (user defined).

In ORWARE, the produced compost/digestate can be routed to a use-on-land module, where environmental consequences of spreading residuals to arable land can be modelled. The composition of biotreated material is calculated based on the waste composition.

\subsection{Decision Support Tool: MSW-DST}

The Integrated Solid Waste Management-Decision Support Tool (MSW-DST) is a model for environmental and economic assessment of integrated waste management systems developed by the Research Triangle Institute (RTI), North Carolina State University and the United States Environmental Protection Agency (USEPA). MSW-DST includes a module for composting of organic MSW (Weitz et al., 1999), eventually pre-treated to reduce contamination.

Two main windrow composting technologies are available, the main difference being whether the composting pad is enclosed in a building or outdoor. In the first case, the waste - mixed household organic waste and garden waste - is shredded in a horizontal hammermill and watered to obtain a moisture content of around $50 \%$ (wet weight). Composting windrows are aerated and occasionally turned by a windrow turner. An odour-control system is installed, but specific gas removal (e.g. $\mathrm{NH}_{3}$ ) is not modelled. Disposal of rejects in landfill is not included in the LCl.

The outdoor windrow facility treats source separated garden waste. Branches are shredded with a tub grinder and no water is added to the feedstock, because garden waste has initial water content already higher than $50 \%$ (wet weight). The windrows are turned monthly with a front loader. No odour control system is installed. A post-processing trommel screen is used to produce a fine compost material.

For all technologies, the MSW-DST model includes specific consumptions of electricity and fuel, as well as emissions from the machineries utilized. The model assumes that during the composting process no $\mathrm{CH}_{4}$ is emitted and that no nitrogen is lost in gaseous form. No leachate control is defined and the model does not calculate the generated amounts and type of substances released to the receiving recipients. 
Compost composition is predefined in the model and thus it is not waste specific. Three compost qualities can be produced: high quality compost (from sorted household waste), low quality compost (from mixed household waste) and garden waste compost. High quality compost and garden waste compost can be used for soil amendment and landscaping at farms, plant nurseries and on derelict land. Low quality compost is to be landfilled.

\subsection{WRATE}

WRATE (Waste and Resources Assessment Tools for the Environment) is an English model for environmental assessment of waste management systems. WRATE was jointly developed by Environmental Resources Management and Golder Associates on behalf of the Environment Agency for England and Wales. WRATE includes a number of biotreatment technology modules based on a consistent process input/output framework. These technologies include 4 types of anaerobic digestion, 10 types of composting and 15 types of MBT-plants as default data.

The composition of the biotreated materials is predefined in the model where four generic grades of biotreated materials can be chosen.

The biotreatment processes include construction, maintenance and decommissioning data. All the direct operating emissions are based on the typical emissions of existing plants (whether measured or estimated). These emissions are directly proportional to the composition (waste specific emissions) and the quantity of waste (process specific emissions) defined by the user.

For anaerobic digestion systems, the quantity of electric energy produced is linearly correlated to the quantity of biogenic carbon in the incoming waste, however, it is not possible to see the quantity of methane produced by such a system. All the typical fugitive emissions (e.g. $\mathrm{CH}_{4}, \mathrm{~N}_{2} \mathrm{O}, \mathrm{NH}_{3}$ ) are defined for each waste management facility. $\mathrm{N}$ emissions are calculated based on the $\mathrm{N}$ content of the incoming waste.

All the biotreatment processes include the management of rejects that can be transported to different technologies (e.g. incineration, landfills, etc.). Default data include the typical quantity and composition of waste rejected from a specific process but can be modified by the expert user.

\subsection{Integrated Waste Management: IWM2}

The Integrated Waste Management (IWM) model was developed by Procter \& Gamble for environmental and economic assessment of waste management systems. Composting and anaerobic digestion are the options available in the module for biological treatment (McDougall et al., 2001). Different technologies can be modelled in each sub-module by defining specific process data and parameters. Different pre-treatment are available prior to the biotreatment.

The anaerobic digestion module calculates the amount of biogas and compost produced based on the mass of organics lost during the process, defined by the user. The amounts of energy used in the process and recovered from biogas are estimated by the user and entered in the model in terms of $\mathrm{kWh} \mathrm{Mg}^{-1}$ wet weight ( $\mathrm{ww}$ ) input to the digester. The value regarding energy production covers a number of other parameters determining the methane yield and recovery, such as the methane potential of the waste, methane and energy contents of the biogas, and engine type and efficiency. Air emissions are included in terms of $\mathrm{CO}_{2}$, generated both from the degradation process and the combustion of biogas. No other air emissions are considered. Liquid residue from the digestion process is routed to wastewater treatment 
plant, but such process is not included in the model. The composition of digestate is predefined in the model. Both the compost and the eventual residue from screening operation can be routed to further treatments (incineration, landfill). Compost can as an alternative be sent out on the market; replacement of mineral fertilizers is modelled by means of default substitution processes.

The composting module calculates the amount of compost produced based on the mass of organics lost during the process, defined by the user. The amount of energy used - which depends on the technology employed - in the process is user defined and entered in the model in terms of $\mathrm{kWh} \mathrm{Mg}^{-1} \mathrm{ww}$ input to composting. Air emissions are included in terms of $\mathrm{CO}_{2}$ generated from the degradation process. No other air emissions are considered. The composition of compost is predefined in the model and its quality determines the final use. Similarly to the digestate, both the compost and the eventual residue from screening operation can be routed to further treatments - compost to use on land and reject to incineration or landfill.

\subsection{WISARD}

WISARD is a waste management life cycle assessment software developed by Ecobilan (France) to assist decision makers when evaluating alternative waste management scenarios (The Ecobilan Group, 2004). WISARD includes generic modules for composting and anaerobic digestion, where case specific parameters - among which construction, maintenance and decommissioning of the plant - are used for modelling treatment facilities defined within the scope of the study.

In WISARD, energy and material consumptions, and the mass balance are calculated on a monthly basis and then converted to process specific data using time-based operational parameters of the facility (e.g. working days per month, tonnage treated per month). Emission factors for different material and processes (e.g. diesel combustion) are included by default, but they can be re-defined by the user. Flows of reject materials can be routed to further treatment or to disposal.

The composition of biotreated material is predefined in the model with varying degree of detail, but the user can customise it to the specific case. The biologically treated material is used on land and different compounds - nitrogen, phosphate, magnesium, and potassium fertilizers, and lime - can be offset, according to some utilization coefficients specific for each compound. The model also calculates leaching to groundwater of nitrate, phosphate and heavy metals. Use of energy for transportation and spreading on land of the stabilized material is accounted for in the model.

The modelling of composting includes also emissions to air of different gases (i.e. $\mathrm{CH}_{4}, \mathrm{NH}_{3}$, $\mathrm{N}_{2} \mathrm{O}$ ) and leaching of different compounds (i.e. organic matter, heavy metals, sulphur, phosphorous) occurring during the process.

The anaerobic digestion module includes modelling of biogas production and utilization. Biogas production is calculated on the amount of putrescible material within the waste using biogas generation values provided by defaults in the database for the landfill gas generation. The composition of biogas $\left(\mathrm{CO}_{2}, \mathrm{CH}_{4}, \mathrm{H}_{2} \mathrm{~S}\right.$, hydrocarbons) is defined on a mass basis $\left(\mathrm{g} \mathrm{kg}^{-1}\right.$ of biogas) and a fraction of its loss between the digester and the generator. The quantity of electricity and heat recovered from biogas utilization is defined on a monthly basis. For the heat recovered, the substituted energy technology is defined by the user - coal, natural gas and oil are the options. 


\subsection{LCA-IWM}

LCA-IWM is a model for assessing the environmental sustainability of municipal waste management planning. It was funded by the European Commission under the Fifth Framework Programme and developed by a cooperation of different institutions (Technical University of Darmstadt, Germany; University of Tarragona, Spain; novaTec, Luxemburg). The model is described in details in De Boer et al. (2005) and De Boer et al. (2007). Anaerobic digestion and composting are the available biological treatments in LCA-IWM. In both cases, mechanical pretreatments are possible and waste characteristic is a user defined input. Default mass flows of the processes are provided by the model, but adjustments can be made by the user.

Anaerobic digestion is defined with a thermophilic dry 1-stage process. Wastewater, biogas, and digestate are the outputs of the process. Biotreated material and wastewater compositions are calculated based on the waste composition. Leaching coefficients are used to determine the distribution of several substances between wastewater and digestate. Wastewater can be routed (user defined) to a wastewater treatment plant, which includes phosphorous removal and sludge stabilisation. Biogas yield is calculated based on methane potential defined by the user (in $\mathrm{m}^{3} \mathrm{Mg}^{-1}$ biowaste), in case taking into account the level of contamination in the waste. The produced biogas is used for energy production in a combustion unit with electricity and (optionally) heat recovery (CHP). The amount of the energy generated is linked to the amount and quality of the biogas, while air emissions of several substances generated during the combustion process are process specific and user defined (in $\mathrm{mg} \mathrm{m}^{-3}$ of flue gas) and should take into consideration a possible installation of an flue gas treatment system. In the default data it is assumed that the CHP is equipped with an oxidative catalytic air cleaning unit. The solid residue produced during the digestion process is aerobically stabilized to produce marketable compost. The maturation phase is 4 weeks long and takes place in windrows in a rotting hall. No air cleaning system is installed. The compost composition is calculated using decomposition rates for $\mathrm{C}$ and $\mathrm{N}$. Emissions to air are modelled using emissions factors describing distribution of degraded $\mathrm{C}$ - and $\mathrm{N}$-containing matter into different compounds (i.e. $\mathrm{CO}_{2}, \mathrm{CH}_{4}, \mathrm{NMVOC}, \mathrm{NH}_{3}, \mathrm{~N}_{2} \mathrm{O}, \mathrm{N}_{2}$ ). It is assumed that no leaching of metals and nutrients occurs during the maturation phase. The produced compost can be further routed to a use on land module. Energy consumptions occurring throughout all phases of the process are summed up to a unique "overall energy consumption" value, which is used in the calculation.

Composting is exemplified with a fully encapsulated composting plant, including a first stage of intensive composting in boxes and a subsequent maturation phase in enclosed windrows. The box composting process takes approximately 11 days. Degradation of organic matter is governed by decomposition rates for $\mathrm{C}$ and $\mathrm{N}$-containing fractions defined by the user. Water and air emissions are calculated using emission factors for distributing the degraded $\mathrm{C}$ - and $\mathrm{N}$-containing matter into different compounds. The maturation phase in windrows is performed in enclosed rotting halls. The modelling of the maturation phase is the same as the one described for the anaerobic digestion process. Both intensive composting and maturation take place in enclosed buildings, the exhaust air generated during the processes is collected and treated in a biofilter. The performance of the biofilter is assessed using removal efficiency values for $\mathrm{CH}_{4}, \mathrm{TOC}, \mathrm{NH}_{3}$, and $\mathrm{N}_{2} \mathrm{O}$. No leaching of metals is assumed to occur during all phases of the composting process, meaning that all metals are transferred into the compost. The produced compost can be further routed to a use on land module. Energy consumption occurring throughout all phases of the process is included in the calculation. 


\section{The biological treatment module in EASEWASTE}

The EASEWASTE model was developed for estimating waste flows, environmental emissions and resource consumption from waste management systems. Similarly to most of the other models, EASEWASTE can be used for assessing whole waste management systems. In addition, it can be used for evaluating the management of single waste material fractions and for comparing different technologies (Christensen et al., 2007). The model was built to be userfriendly, well-documented, transparent and flexible (Kirkeby et al., 2006), but the complexity provided by the model allows the user to include a variety of aspects, processes and subprocesses commonly present in waste management system. EASEWASTE can easily be adjusted to properly cover the temporal and spatial scopes of the study, while distributing the emissions to a large range of potential impact categories. EASEWASTE supports LCA studies throughout the four above mentioned LCA phases and can deliver results both as an inventory of emissions and potential environmental impacts (characterised, normalised or weighted). A novelty of the model is that consistent results are ensured with a material- and substancebalance approach. An overview of the different features included in the EASEWASTE model is provided in Table 1.

Table 1 - Overview of features included in the reviewed models ( $\checkmark$ =included/available; na $=$ not available or not accessible).

\begin{tabular}{|c|c|c|c|c|c|c|c|c|}
\hline Biological Treatment & 를 & 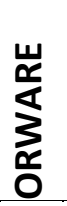 & 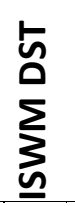 & 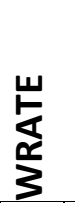 & $\sum_{\underline{\Sigma}}^{\mathfrak{N}}$ & 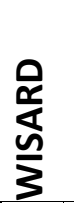 & 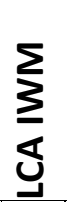 & 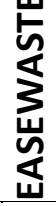 \\
\hline Biotreated material depends on waste composition & $\checkmark$ & $\checkmark$ & na & na & na & na & na & $\checkmark$ \\
\hline Compost modelling & $\checkmark$ & $\checkmark$ & $\checkmark$ & $\checkmark$ & $\checkmark$ & $\checkmark$ & $\checkmark$ & $\checkmark$ \\
\hline Anaerobic digestion modelling & $\checkmark$ & $\checkmark$ & na & $\checkmark$ & $\checkmark$ & $\checkmark$ & $\checkmark$ & $\checkmark$ \\
\hline MBT modelling & na & na & na & $\checkmark$ & na & na & na & $\checkmark$ \\
\hline Sludge modelling & na & $\checkmark$ & na & na & na & na & na & na \\
\hline Other Organic waste management & na & $\checkmark$ & na & na & na & na & na & na \\
\hline Methane potential & $\checkmark$ & $\checkmark$ & na & na & $\checkmark$ & na & $\checkmark$ & $\checkmark$ \\
\hline Methane content in biogas & $\checkmark$ & $\checkmark$ & na & na & $\checkmark$ & na & na & $\checkmark$ \\
\hline Methane production & $\checkmark$ & $\checkmark$ & na & $\checkmark$ & $\checkmark$ & na & na & $\checkmark$ \\
\hline Unburnt methane (Fugitive emissions) & $\checkmark$ & na & $\checkmark$ & $\checkmark$ & na & na & na & $\checkmark$ \\
\hline Total N Loss & $\checkmark$ & $\checkmark$ & na & $\checkmark$ & na & $\checkmark$ & na & $\checkmark$ \\
\hline VOC emissions & na & $\checkmark$ & $\checkmark$ & $\checkmark$ & na & $\checkmark$ & $\checkmark$ & $\checkmark$ \\
\hline Distribution of $\mathrm{N}$ loss $\left(\mathrm{NH}_{3}, \mathrm{~N}_{2} \mathrm{O}, \mathrm{N}_{2}\right)$ & $\checkmark$ & $\checkmark$ & $\checkmark$ & $\checkmark$ & na & na & $\checkmark$ & $\checkmark$ \\
\hline Gas cleaning $\left(\mathrm{NH}_{3}, \mathrm{~N}_{2} \mathrm{O}, \mathrm{CH}_{4}\right)$ & $\checkmark$ & $\checkmark$ & $\checkmark$ & $\checkmark$ & na & na & na & $\checkmark$ \\
\hline Energy produced & $\checkmark$ & $\checkmark$ & $\checkmark$ & $\checkmark$ & $\checkmark$ & $\checkmark$ & $\checkmark$ & $\checkmark$ \\
\hline Compost degradation coefficient & $\checkmark$ & $\checkmark$ & $\checkmark$ & $\checkmark$ & na & na & na & $\checkmark$ \\
\hline Biogas degradation coefficient & na & $\checkmark$ & $\checkmark$ & $\checkmark$ & na & na & na & $\checkmark$ \\
\hline Biotreatment rejects & na & $\checkmark$ & $\checkmark$ & $\checkmark$ & na & $\checkmark$ & na & $\checkmark$ \\
\hline Retention time modelling & na & $\checkmark$ & $\checkmark$ & $\checkmark$ & na & na & na & na \\
\hline Variable Retention time modelling & na & na & na & $\checkmark$ & na & na & na & na \\
\hline
\end{tabular}




\subsection{Approach and structure}

The module for biological treatment of organic municipal waste in EASEWASTE includes modelling of:

- anaerobic digestion;

- composting;

- combined anaerobic digestion and composting;

- Mechanical-Biological-Treatment (MBT) plants for treatment of mixed residual waste. A Material Recovery Facility (MRF) module can be placed prior to the biological treatment module in EASEWASTE to model specific sorting/screening operations in the system.

Generation, collection and pre-treatment of the waste are assessed in associated modules in the model, positioned prior to the biological treatment module. By defaults, EASEWASTE operates with 48 waste material fractions, each described by 40 physical-chemical parameters - the list can be found in Kirkeby et al. (2006). Default datasets are available, but all parameter values can be changed by the user (Kirkeby et al., 2006). In the module, the biological degradation of organic matter (Volatile Solids, VS) and the distribution of the remaining material between the output fractions are defined for each waste material fraction (vegetable food waste, animal food waste, ornamental flowers, etc.). Each of the output flows from biological treatment can be routed to other modules, where further treatment or disposal is modelled and assessed. Both source-separated and mixed waste can be treated in the biological treatment module. The module employs process-specific material and energy use (mass/energy per $\mathrm{Mg}$ of waste processed) as well as process-specific emissions. Processspecific emissions are categorized according to the receiving compartment (air, surface water, soil, etc.). Emissions of $\mathrm{CH}_{4}, \mathrm{NH}_{3}$ and $\mathrm{N}_{2} \mathrm{O}$ are modelled as a function of the degradation of $\mathrm{C}$ and $\mathrm{N}$-containing compounds. When possible, data regarding emissions should be gathered and modelled specifically for the assessed facility, as done for example in Andersen et al. (2010)".

\subsection{Dry matter flows}

In EASEWASTE, the composition of biotreated material is calculated based on material input composition by means of degradation ratios and transfer coefficients. These choices intend to make the model more realistic and precise, avoiding the risk of a too simplified approach, which might often produce the same results, regardless of aspects such as the country and the waste composition in question. Furthermore, a modelling based on the waste composition is useful for investigating diversion of waste material fractions to alternative treatments and for identifying the origin of pollutants contained in the compost.

The degradation of the organic material (VS) for each waste material fraction is user defined. As explained later, the VS degradation is calculated based on the methane potential and methane yield in case of anaerobic digestion. For composting, the degradation is expressed as degradation ratio (\% of VS) of the VS input. Such coefficients must be defined for each waste material fraction undergoing biological treatment, because the degradability can vary considerably among them. Food waste is relatively easy degradable, while paper or wooden materials degrade slowly. Waste material fractions with degradation ratio $>0$ are defined as "degradable", while waste material fractions with degradation ratio $=0$ are defined as "non-degradable". The model assumes that the non-degradable fractions (i.e. glass and plastic) go unaltered through the biological treatment: their dry matter composition does not change and they do not contribute to any emissions. The amount and composition of the 
degradable material fractions change during the process as they are degraded and may cause emissions to different environmental compartments. The model assumes that all the ash and heavy metals contained in the waste are not degraded during the biological process and transferred to the compost composition - i.e. the amount of ash and heavy metals remain unaltered for all waste material fractions during the treatment (it is assumed that no leaching during the treatment is occurring).

The non-degraded dry matter (TS) from each material fraction is distributed between the defined output fractions (e.g. compost, rejects) according to user defined transfer coefficients (TCs). The TCs govern the distribution of dry matter to the outputs according to Equation 1. Transfer coefficients must be defined for each input material fraction. The TCs matrix thus consist of $f$ columns (i.e. number of output fractions) and $x$ rows (i.e. number of input material fractions). The mass balancing approach is linear, as in the LCA context a process is treated as a "black box" and the user is responsible for defining proper TCs describing the actual biological process.

$$
T S_{\text {out }, x}=\sum_{f=1}^{n}\left(T S_{b i o, f} \times T C_{x, f}\right) \quad \text { Equation } 1
$$

Where:

$T S_{\text {out }, x}[\mathrm{~kg}]$ is the amount of TS in the output $x$

$T S_{b i o, f}[\mathrm{~kg}]$ is the amount of TS left in waste fraction $f$ after biological degradation

$T C_{x, f}[0-1]$ is the TC for fraction $f$ into output $x$

The transfer coefficients are mass conserving and, considering all outputs, add up to 1 for each waste material fraction. The number and type of outputs fractions - up to eight - can be specified for each technology. The water content of each output fraction is user defined. Each output fraction can be routed further downstream in the model. Transportation distance and type for each of them can be defined. Available subsequent modules are: Use-on-land, energy utilization, landfilling, material recycling, material utilization, thermal treatment.

Other non-solid outputs, emissions and pollution control devices are specific for the chosen treatment within the three technologies: composting, anaerobic digestion and a combination thereof.

\subsection{Composting}

Any kind of composting technology can be assessed in the composting module: open, enclosed, reactor technologies, and home composting. The main differences between the technologies are in the energy consumption (both electricity and fuel) and emission control systems.

Any kind of biodegradable waste can be composted in theory. In practice, only few types of organic waste are composted in significant amounts in dedicated plants: kitchen organic waste, garden waste and sludge (Boldrin et al., 2009). In addition, large amounts of mixed waste are composted in MBT facilities. Composting of organic municipal waste requires in most cases mixing of structure material to optimise both the physical structure and chemical properties (e.g. $\mathrm{C} / \mathrm{N}$ ratio) of the feedstock. The structure material often consists of garden waste. If the focus of the assessment is solely the treatment of food waste, allocation of energy/materials uses and emissions must be done while preparing the inventory of the specific facility. 
The composting module includes a sub-module for emissions to air of carbon-containing and nitrogen-containing compounds. If a biofilter is installed, removal efficiencies for $\mathrm{NH}_{3}, \mathrm{~N}_{2} \mathrm{O}$ and $\mathrm{CH}_{4}$ can be specified by the user, who should make sure that the data used are casespecific and representative (e.g. of the variability) of the situation under assessment. The module calculates by default the degraded $\mathrm{C}$-containing matter and $\mathrm{CO}_{2}$ emission to air using the VS degradation ratios specified by the user, assuming that degradation of carbon compounds is proportional to VS degradation. The amount of C-containing gaseous emissions ( $\mathrm{C}_{\text {air }}$ expressed as $\mathrm{kg}$ of $\mathrm{C}$ ) is calculated according to Equation 2:

$$
C_{\text {air }}=M_{t} \times \sum_{f=1}^{n}\left(m_{f} \times T S_{f} \times C_{f} \times V S_{\text {deg,f }}\right) \quad \text { Equation } 2
$$

Where:

$M_{t}[\mathrm{~kg}]$ is the input waste mass

$m_{f}[0-1]$ is the mass fraction of the waste material fraction $f$ in the waste

$T S_{f}[0-1]$ is the fraction of dry matter content of fraction $f$

$C_{f}[0-1]$ is the carbon content (fraction of TS) for fraction $f$

$V S_{\text {deg, } f}[0-1]$ is the VS degradation ratio for fraction $f$ (user defined)

Equation 2 is based on total carbon content. Ideally, the release of fossil carbon and the impact related to it should be calculated separately. However, in waste material fractions such as organic waste the content of $\mathrm{C}$-fossil is relatively small and, therefore, the degradation of Cfossil compounds during the processes under consideration is considered negligible.

The model estimates emissions of $\mathrm{CO}_{2}$ and $\mathrm{CH}_{4}$ in relation to the amount of carbon released to atmosphere. Other C-containing trace gases (e.g. CO) could be emitted during biological processes. These emissions can be defined as process-specific - i.e. per amount of treated waste - in the model. The amount of $\mathrm{CO}_{2}$ emitted is linked to the amount of degraded $\mathrm{C}$ containing matter $\left(\mathrm{C}_{\text {air }}\right.$ ) previously calculated minus the fraction of carbon emitted as $\mathrm{CH}_{4}$. In addition, $\mathrm{CO}_{2}$ is generated by methane oxidation in the biofilter if present. The amount [kg] of $\mathrm{CO}_{2}$ emitted to atmosphere $\left(\mathrm{CO}_{2}\right.$,air $)$ is calculated according to Equation 3:

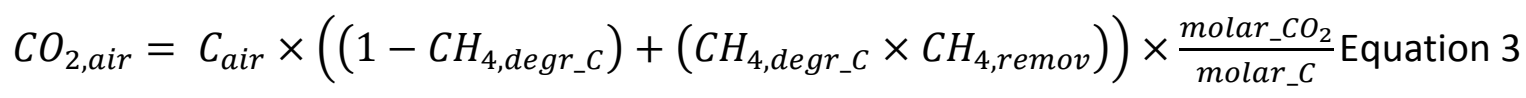

Where:

$C_{\text {air }}[\mathrm{kg}$ of $\mathrm{C}]$ is the amount of $\mathrm{C}$-containing gaseous emissions (calculated with Eq. 2)

$\mathrm{CH}_{4, \text { degr_c }}$ [0-1] is the fraction of $\mathrm{C}_{\text {air }}$ emitted as $\mathrm{CH}_{4}$ (user defined)

$\mathrm{CH}_{4, \text { remov }}[0-1]$ is the $\mathrm{CH}_{4}$ removal (oxidation) efficiency in the biofilter (user defined). If a biofilter is not present, $\mathrm{CH}_{4, \text { remov }}=0$

molar_ $\mathrm{CO}_{2}$ and molar_C $\left[\mathrm{g}\right.$ mole $\left.{ }^{-1}\right]$ are the molar weights of $\mathrm{CO}_{2}$ and $\mathrm{C}$

Composting can result in $\mathrm{CH}_{4}$ emissions if composting heaps are not properly managed and anaerobic conditions occur. The amount of methane released to the atmosphere, which depends on how the plant is operated, is user defined as a percent of the degraded Ccontaining matter. If a biofilter is installed, $\mathrm{CH}_{4}$ removal efficiency is also to be specified. The amount of $\mathrm{CH}_{4}[\mathrm{~kg}]$ emitted to atmosphere $\left(\mathrm{CH}_{4, \text { air }}\right)$ is calculated according to Equation 4:

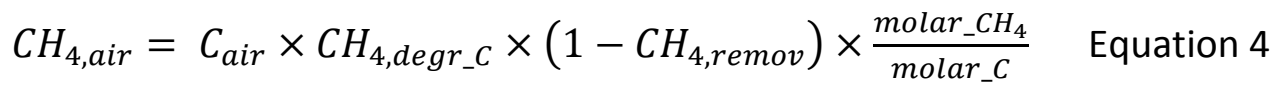


Where:

$\mathrm{C}_{\text {air }}[\mathrm{kg}$ of $\mathrm{C}]$ is the amount of $\mathrm{C}$-containing gaseous emissions (calculated with Eq. 2)

$\mathrm{CH}_{4, \text { degr_c }} \mathrm{O}$-1 1 is the fraction of $\mathrm{C}_{\text {air }}$ emitted as $\mathrm{CH}_{4}$ (user defined)

$\mathrm{CH}_{4, \text { remov }}$ ) [0-1] is the $\mathrm{CH}_{4}$ removal (oxidation) efficiency in the biofilter (user define). If a biofilter is not present, $\mathrm{CH}_{4, \text { remov }}=0$

molar_ $\mathrm{CH}_{4}$ and molar_C $\left[\mathrm{g}\right.$ mole ${ }^{-1}$ ] are molar weights of $\mathrm{CH}_{4}$ and $\mathrm{C}$

During the composting process, part of the nitrogen contained in the waste is degraded and eventually emitted to atmosphere. The total amount of nitrogen lost (as \% of total $\mathrm{N}$ ) and its distribution among ammonia $\left(\mathrm{NH}_{3}\right)$, nitrous oxide $\left(\mathrm{N}_{2} \mathrm{O}\right)$ and nitrogen $\left(\mathrm{N}_{2}\right)$ is user specified in EASEWASTE. The degradation of nitrogen compounds is not controlled by VS degradation ratios, because the degradation patterns are different and because some of the $\mathrm{N}$ could come from the inorganic matrix of the waste - in other words the $\mathrm{N}$ degradation is not proportional to VS degradation. If gaseous emissions are treated in a gas-cleaning device (e.g. biofilter), removal efficiencies for $\mathrm{NH}_{3}$ and $\mathrm{N}_{2} \mathrm{O}$ must be defined. The amount of $\mathrm{N}$-containing gaseous emissions ( $\mathrm{N}_{\text {air }}$, expressed as $\mathrm{kg}$ of $\mathrm{N}$ ) generated during the composting process is calculated according to Equation 5:

$N_{\text {air }}=M_{t} \times \sum_{f=1}^{n}\left(m_{f} \times T S_{f} \times N_{f} \times N_{\text {deg }}\right) \quad$ Equation 5

Where:

$M_{t}[\mathrm{~kg}]$ is the input waste mass

$m_{f}[0-1]$ is the mass fraction of the material fraction $-f$ in the waste

$T S_{f}[0-1]$ is the dry matter content (fraction of TS) of fraction $f$

$N_{f}[0-1]$ is the nitrogen content (fraction of TS) of fraction $f$

$N_{\text {deg,f }}[0-1]$ is the $\mathrm{N}$ compounds degradation ratio (same for all fractions)

Specific emissions to atmosphere of $\mathrm{NH}_{3}\left(\mathrm{NH}_{3}\right.$,air $)$ and $\mathrm{N}_{2} \mathrm{O}\left(\mathrm{N}_{2} \mathrm{O}_{\text {air }}\right)$ are calculated according to Equation 6 and Equation 7:

$$
\begin{aligned}
& \mathrm{NH}_{3, \text { air }}=N_{\text {air }} \times \mathrm{NH}_{3, \text { degr } \_N} \times\left(1-\mathrm{NH}_{3, \text { remov }}\right) \times \frac{\text { molar } \mathrm{NH}_{3}}{\text { molar } N} \quad \text { Equation } 6
\end{aligned}
$$

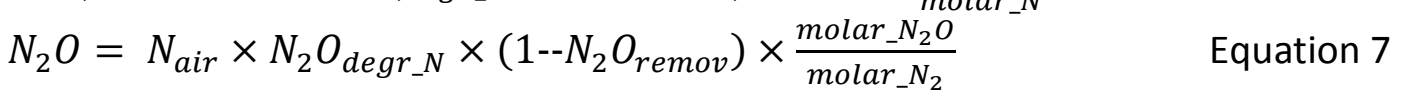

Where:

$\mathrm{NH}_{3, \text { remov }}$ and $\mathrm{N}_{2 \text {,remov }}$ [0-1] are the removal efficiencies in the biofilter (user defined).

$\mathrm{NH}_{3, \text { degr_N }}[0-1]$ is the fraction of $\mathrm{N}_{\text {air }}$ emitted as $\mathrm{NH}_{3}$ (user defined)

$\mathrm{N}_{2} \mathrm{O}_{\text {degr }} \mathrm{N}$ [0-1] is the fraction of $\mathrm{N}_{\text {air }}$ emitted as $\mathrm{N}_{2} \mathrm{O}$ (user defined)

molar_ $\mathrm{NH}_{3}$, molar_ $\mathrm{N}_{2} \mathrm{O}$, molar_N $\left[\mathrm{g}\right.$ mole $\left.{ }^{-1}\right]$ are molar weights of $\mathrm{NH}_{3}, \mathrm{~N}_{2} \mathrm{O}$ and $\mathrm{N}$.

\subsection{Anaerobic digestion}

Different anaerobic digestion technologies for organic waste can be modelled in this module: wet, dry, and semidry as well as one and two steps processes. The main differences between different anaerobic digestion technologies will be energy consumption, emissions of unburned methane and energy production. In case of co-digestion with other organic materials, proper allocations must be made for the two substrates, but the co-substrate is 
normally not included in the inventory. However, if the co-substrates are assessed to influence the degradation of the organic waste, this can be reflected in the methane yield determining the gas production. Moreover, the output fractions represent only the degraded waste and not the mix of waste and co-substrates. EASEWASTE assumes that no emissions of nitrogen containing substances occur during the digestion process.

The methane potential as STP $\mathrm{m}^{3} \mathrm{~kg}^{-1}$ VS is defined for each waste material fraction as a part of the chemical composition table in the EASEWASTE database. However, because the degradability of the substrate depends on the types of organic matter in question, as a general rule EASEWASTE considers that the methane generation is not proportional to the VS degradation rate (it may be for highly degradable waste fractions). For instance, if the organic substrate contains relevant amount of lignin, $100 \%$ of the methane potential could be reached during the digestion process, while most of the VS is not degraded. Therefore, a new coefficient expressing the obtained fraction (the yield) of the $\mathrm{CH}_{4}$ potential is to be defined by the user. This approach was chosen to avoid overestimating methane production, while still being able to investigate single waste material fractions. The methane production $\left(\mathrm{CH}_{4, \text { prod }}\right)$ is therefore calculated (in $\mathrm{m}^{3}$ ) according to Equation 8:

$$
\mathrm{CH}_{4, \text { prod }}=M_{t} \times \sum_{f=1}^{n}\left(m_{f} \times T S_{f} \times V S_{f} \times \mathrm{CH}_{4, p o t, f} \times \mathrm{CH}_{4, \text { yield }, f}\right) \quad \text { Equation } 8
$$

\section{Where:}

$M_{t}[\mathrm{~kg}]$ is the input waste mass

$m_{f}[0-1]$ is the mass fraction of the waste material fraction $f$ in the waste

$T S_{f}[0-1]$ is the dry matter content (fraction of TS) of fraction $f$

$V S_{f}[0-1]$ is the VS (fraction of TS) content of fraction $f$

$\mathrm{CH}_{4, p o t, f}\left[\mathrm{STPm}^{3} \mathrm{kgVS}^{-1}\right]$ is the $\mathrm{CH}_{4}$ potential of fraction $f$

$\mathrm{CH}_{4, \text { yield,f }}[0-1]$ is the obtained fraction of $\mathrm{CH}_{4}$ potential for fraction $f$ (user defined)

A fraction of the generated $\mathrm{CH}_{4}$ is emitted to the atmosphere, because of fugitive losses from leaks in pipes, valves, etc. The amount $(\mathrm{kg})$ of $\mathrm{CH}_{4}$ emitted to air $\left(\mathrm{CH}_{4}\right.$,air $)$ is calculated according to Equation 9:

$$
\mathrm{CH}_{4, \text { air }}=\mathrm{CH}_{4, \text { prod }} \times \mathrm{CH}_{4, \text { unrec }} \times \frac{\text { molar_CH} H_{4}}{\text { Vol_idealgas }} \quad \text { Equation } 9
$$

Where:

$\mathrm{CH}_{4, \text { prod }}\left[\mathrm{m}^{3}\right]$ is the amount of $\mathrm{CH}_{4}$ generated (calculated with Eq. 8)

$\mathrm{CH}_{4 \text {, unrecov }}[0-1]$ is the fraction of generated $\mathrm{CH}_{4}$ not recovered (fugitive emission)

molar_ $\mathrm{CH}_{4}\left[\mathrm{~g} \mathrm{~mole} \mathrm{~m}^{-1}\right]$ is the molar weight of $\mathrm{CH}_{4}$

Vol_idealgas $\left[\mathrm{m}^{3} \mathrm{~mole}^{-1}\right]$ is the ideal volume of 1 mole of gas at STP.

The degraded C-containing matter during the anaerobic digestion leaves the process as biogas, either as $\mathrm{CO}_{2}$ or $\mathrm{CH}_{4}$. EASEWASTE calculates the amount of degraded C-containing matter during anaerobic digestion using the methane production (previously defined) and the $\mathrm{CH}_{4}$ content in the biogas. In this way, the user is fully in control of the process parameters and any kind of technology can be modelled. The amount of degraded C-containing matter and emitted to air $\left(\mathrm{C}_{\text {air }}\right)$ is calculated according to Equation 10: 


$$
C_{\text {air }}=\frac{\mathrm{CH}_{4, \text { prod }}}{\frac{\mathrm{CH}_{4, \% \_ \text {biogas }} \times \text { Vol_idealgas }}{100} \times \text { Molar }_{-} C \quad \text { Equation } 10}
$$

Where:

$\mathrm{CH}_{4, \text { prod }}\left[\mathrm{m}^{3}\right]$ is the amount of $\mathrm{CH}_{4}$ generated (calculated with Eq. 8)

$\mathrm{CH}_{4, \% \text { biogas }}[0-1]$ is the $\mathrm{CH}_{4}$ content in biogas (user defined)

Vol_idealgas $\left[\mathrm{m}^{3} \mathrm{~mol}^{-1}\right]$ is the ideal volume of 1 mole of gas at STP.

molar_C $\left[\mathrm{kg} \mathrm{mole}^{-1}\right]$ is the molar weight of $\mathrm{C}$

Carbon dioxide $\left(\mathrm{CO}_{2}\right)$ is generated during the digestion process (contained in biogas) and from the combustion of biogas. In other terms, this can be calculated from the degraded $\mathrm{C}$ minus the carbon contained in fugitive emissions of $\mathrm{CH}_{4}$ from the reactor. The amount of $\mathrm{CO}_{2}(\mathrm{~kg})$ emitted to atmosphere $\left(\mathrm{CO}_{2}\right.$,air $)$ is calculated according to Equation 11:

$$
\mathrm{CO}_{2, \text { air }}=\left(\frac{\mathrm{C}_{\text {air }}}{\text { molar } \_}-\frac{\mathrm{CH}_{4, \text { air }}}{\text { molar }_{-} \mathrm{CH}_{4}}\right) \times \text { molar }_{-} \mathrm{CO}_{2} \quad \text { Equation } 11
$$

Where:

$C_{\text {air }}[\mathrm{kg}$ of $\mathrm{C}]$ is the amount of $\mathrm{C}$-containing gaseous emissions (calculated with Eq. 10)

$\mathrm{CH}_{4, \text { air }}[\mathrm{kg}]$ is the amount of $\mathrm{CH}_{4}$ emitted to air (calculated with Eq. 9)

molar_ $\mathrm{CO}_{2}$, molar_CH , molar_C $\left[\mathrm{g}\right.$ mole $\left.{ }^{-1}\right]$ are the molar weights of $\mathrm{CO}_{2}, \mathrm{CH}_{4}, \mathrm{C}$

In EASEWASTE, the biogas produced during anaerobic digestion can be flared, combusted in an engine or upgraded and used as fuel in motor vehicles. Biogas flaring is used to oxidize $\mathrm{CH}_{4}$ to $\mathrm{CO}_{2}$, without energy recovery.

The amount (MJ) of energy recovered (Energy rec) from biogas depends on the amount and energy content of $\mathrm{CH}_{4}$ recovered from the digestion process; it is calculated according to Equation 12:

$$
\text { Energy } y_{\text {rec }}=\mathrm{CH}_{4, \text { prod }} \times\left(1-\mathrm{CH}_{4, \text { unrec }}\right) \times \text { Energy }_{\mathrm{CH}_{4}} \quad \text { Equation } 12
$$

Where:

$\mathrm{CH}_{4, \text { prod }}\left[\mathrm{m}^{3}\right]$ is the amount of $\mathrm{CH}_{4}$ generated (calculated with Eq. 8)

$\mathrm{CH}_{4 \text {, unrecov }}[0 \rightarrow 1]$ is the fraction of generated $\mathrm{CH}_{4}$ not recovered (fugitive emission)

Energy $_{\mathrm{CH} 4}\left[\mathrm{MJ}\right.$ STP $\mathrm{m}^{-3}$ ] is the energy content of methane

Utilization of biogas for energy purposes is performed in a separate module in EASEWASTE called "biogas treatment" - which is used for both energy production and upgrading of biogas to fuel for motor vehicles. Such module is divided in two parts. The first is used to determine the energy recovery: the user defines the type of energy produced by the engine (usually electricity, eventually heat), the recovery efficiency for each type of energy and the marginal energy production process which is substituted. The second part is used to specify the processspecific emissions (e.g. $\mathrm{CH}_{4}, \mathrm{NO}_{x}, \mathrm{CO}, \mathrm{N}_{2} \mathrm{O}$, and $\mathrm{SO}_{2}$ ) regarding the process for combustion of biogas - in engines or in vehicle motors. 


\subsection{Combined technology}

Several technologies combining anaerobic digestion and composting exist. Some plants combine the two technologies within the same reactor by changing between anaerobic and aerobic conditions during the treatment process. Other plants perform anaerobic digestion in reactors followed by windrow composting of the digested material. This is a technology area under development and many different combinations have been introduced.

The modelling of the combined process is a combination of the modules for anaerobic digestion and composting described above. The mathematical description thus consists of the equations presented above for anaerobic digestion and composting. For each of the waste material fractions entering the process, the user must define $\mathrm{CH}_{4}$ yield and a VS degradation ratio. Digestion of organic substance is performed before composting, the order cannot be changed. The model estimates the chemical-physical composition of the material entering the composting stage taking into consideration the biodegradation - described by the $\mathrm{CH}_{4}$ yield matrix - occurring inside the $A D$ reactor.

\subsection{Mechanical Biological Treatment (MBT)}

Mechanical-Biological Treatment (MBT) is a generic term used with regard to systems developed for the treatment of household and commercial waste and, if properly designed, also for bulky waste, where mechanical (e.g. crushers, sieves, air classifiers) and biological or physical processing are performed. Waste treatment in an MBT facility is performed to reduce the volume of waste and to modify its chemical-physical properties.

MBT processes are normally classified into three types, according to the technology employed and the nature of materials recovered:

- Mechanical Biological Pre-treatment prior to landfill (MBP): a mechanical step is used to crush, sieve and recover different material fractions - primarily a Refused Derived Fuel (RDF) fraction for energy production. The residual flow containing large amounts of organic materials is biodegraded (aerobic or anaerobic treatment) and disposed in landfills.

- Mechanical Biological Stabilization (MBS): the waste is undergoing biological treatment aiming to dry the waste while preserving the energy content. A mechanical step is employed afterwards to recover valuable materials (i.e. metals and mineral), while the remaining fraction is used as RDF for energy production.

- Mechanical Physical Stabilization (MPS): same principle as MBS systems, but the drying process is performed with physical process having additional energy requirements.

In EASEWASTE, a MBT plant can be defined in different ways, depending on the types of processes adopted. The MBP and MBS plants are modelled using the mathematical equations presented for the composting module or the anaerobic digestion module - depending on the technology employed at the facility for the stabilisation of the organic fraction of the waste and employing appropriate parameters for describing the actual facility under assessment.

The screening (sorting) performed after the biological step is included using transfer coefficients to distribute the TS to the different output fractions. In case of MBP facilities, a screening step is also performed before the biological treatment to recover the RDF fraction. This is modelled in EASEWASTE by using a Material Recovery Facility (MRF) module in front of the biotech module. The composting module is also used for the MPS system: the water content in the output is adjusted according to the drying procedure and if any degradation occurs the VS degradation table is used to properly model it. 
The RDF produced can be routed to different options: energy utilization by co-combustion in coal fired power plant and cement kilns, and thermal treatment by co-incineration in wasteto-energy plant, or incineration in RDF power plant. These options differ in technical aspects - e.g. energy recovery efficiencies, flue gas cleaning system - and substitution patterns - i.e. co-combustion offset directly the use of coal, while incineration produces energy offsetting marginal energy on the grid.

\section{EASEWASTE modelling of existing biological treatment facilities}

Four examples of existing treatment facilities have been chosen to illustrate the $\mathrm{LCl}$ modelling, two based on composting systems, one based on anaerobic digestion and one technology combining anaerobic digestion and composting. The illustrative cases aim to show that the model can assess environmental performances of different alternatives in function of the technology and management employed. It should be noted that the comparison of the below described alternative is meant to illustrate the main differences among technologies and to emphasize the most significant modelling parameters. Thus conclusions on the performance of the technologies at a system level - and especially for other countries than Denmark should not be drawn, because local conditions and case-specific data (e.g. waste composition, electricity mix, management, etc.) might be relevant for the results.

\subsection{Description of treatment facilities}

LCl modelling parameters for the selected technologies are reported in Table 2. A brief description of the technologies is reported below, including background information for the establishment of the LCls.

- Windrow composting system (T1) for the treatment of source-separated organic waste (kitchen waste and garden waste) and production of high quality compost suitable for soil amendment and landscaping at plant nurseries, on construction sites, and on derelict land. A MRF (not included in the current $L C l$ ) is used to remove foreign items and impurities prior to the composting process. Initially the waste is shredded in a horizontal hammermill and watered to obtain a moisture content around 50\% (wet weight). Composting takes place in aerated windrows. The windrows are occasionally turned by a windrow turner. A trommel screen is used to produce fine compost after the curing phase. Rejects are landfilled. The $\mathrm{LCl}$ is based on Komilis \& Ham (2000), Ham \& Komilis (2003), and Komilis \& Ham (2004).

- Tunnel composting system (T2) for the treatment of source-separated organic waste $(2 / 3$ kitchen waste and $1 / 3$ garden waste as structure material) and production of high quality compost sold as a fertilizer for agricultural and horticultural purposes. Garden waste is shredded and stored until it is used. Kitchen waste is received and screened to remove large foreign items (100 mm sieve, primarily plastic bags which are landfilled). Garden waste and kitchen waste are mixed and loaded into the tunnels (7 meters wide and 90 meters long). Mechanical turning of the feedstock is performed automatically every $6^{\text {th }}$ day. Ventilation is performed by constant insufflation of air from the bottom of the tunnel. The building is kept humid and under-pressured in order to prevent spreading of odours and bio-aerosols in the surrounding area. Exhaust gases from the composting process are treated with a biofilter (compost + structure material such as bark or garden waste). Composting time is approximately 11 weeks. Afterwards, feedstock is unloaded, screened with a $15 \mathrm{~mm}$ sieve and laid in open cells for the final maturation. The rejects from the second screening are sent to landfill. The LCl was developed by the authors based on data and documentation 
supplied by the plant management, including amount and composition of input waste and output materials (compost and rejects), gaseous emissions measured after the biofilter and consumption of energy and materials.

Table 2 - LCI modelling parameters for different technologies.

\begin{tabular}{|c|c|c|c|c|c|}
\hline $\begin{array}{l}\text { Location } \\
\text { Scenario name }\end{array}$ & Unit & $\begin{array}{l}\text { Composting, } \\
\text { Windrow } \\
\text { USA } \\
\text { T1 }\end{array}$ & $\begin{array}{l}\text { Composting, } \\
\text { Tunnel } \\
\text { Italy } \\
\text { T2 }\end{array}$ & $\begin{array}{c}\text { AD, one stage } \\
\text { wet } \\
\text { West Europe } \\
\text { T3 }\end{array}$ & $\begin{array}{c}\text { Combined } \\
\text { technology } \\
\text { Denmark } \\
\text { T4 }\end{array}$ \\
\hline \multicolumn{6}{|c|}{ Mass balance (for vegetable food waste) } \\
\hline TS distribution: Compost & $\%$ & 95 & 95 & - & $100^{*}$ \\
\hline Digestate & $\%$ & - & - & 100 & - \\
\hline Rejects & $\%$ & 5 & 5 & 5 & 5 \\
\hline VS degradation: digestion & $\%$ VS input & - & - & calc. & calc. \\
\hline composting & $\%$ VS input & 67 & 73.5 & - & 13.5 \\
\hline $\mathrm{CH}_{4}$ yield - kitchen waste & $\% \mathrm{CH}_{4}$ pot. & - & - & 70 & $50^{* *}$ \\
\hline C degradation & $\%$ VS input & 67 & 73.5 & calc. & calc. \\
\hline TS in compost & $\%$ of ww & 60 & 64.5 & - & $64^{*}$ \\
\hline TS in digestate & $\%$ of ww & - & - & 3 & - \\
\hline \multicolumn{6}{|l|}{ Process-specific inputs } \\
\hline Diesel $^{* * *}$ & $\mathrm{LMg}^{-1} \mathrm{wW}$ & 1.3 & - & 0.9 & 0.9 \\
\hline Electricity & $\mathrm{kWh} \mathrm{Mg}{ }^{-1} \mathrm{ww}$ & 150 & 53.4 & 48.9 & 21 \\
\hline \multicolumn{6}{|c|}{ Waste-specific emissions to air } \\
\hline $\mathrm{CH}_{4}$ fugitive & $\% \mathrm{CH}_{4}$ produced & - & - & 2 & 1.2 \\
\hline $\mathrm{CH}_{4}$ to air & $\%$ degraded C & 0 & 0.2 & - & 3.9 \\
\hline N loss & $\%$ total $\mathrm{N}$ & 65 & 71 & - & $67^{* * * *}$ \\
\hline $\mathrm{NH}_{3}$ to air & $\% \mathrm{~N}$ loss & 96 & 89.5 & - & 96 \\
\hline $\mathrm{N}_{2} \mathrm{O}$ to air & $\% \mathrm{~N}$ loss & 2 & 1.4 & - & 0.78 \\
\hline $\mathbf{N}_{2}$ to air & $\% \mathrm{~N}$ loss & 2 & 0.1 & - & 3.2 \\
\hline \multicolumn{6}{|l|}{ Gas cleaning } \\
\hline $\mathrm{NH}_{3}$ & $\%$ removal & 90 & 99 & - & 98 \\
\hline $\mathrm{N}_{2} \mathrm{O}$ & \% removal & 0 & 0 & - & 0 \\
\hline $\mathrm{CH}_{4}$ & $\%$ removal & 90 & 95 & - & 0 \\
\hline \multicolumn{6}{|c|}{ Process-specific emissions to air (after eventual biofilter) } \\
\hline VOC & $\mathrm{kg} \mathrm{Mg}^{-1} \mathrm{ww}$ & 0.001 & - & - & - \\
\hline NOx & $\mathrm{kg} \mathrm{Mg}^{-1} \mathrm{ww}$ & - & - & - & $1 e^{-3}$ \\
\hline $\mathrm{SO}_{2}$ & $\mathrm{~kg} \mathrm{Mg}^{-1} \mathrm{ww}$ & - & - & - & $5 e^{-5}$ \\
\hline Limonene & $\mathrm{kg} \mathrm{Mg}^{-1} \mathrm{ww}$ & - & $0.26 \mathrm{e}^{-3}$ & - & - \\
\hline \multicolumn{2}{|c|}{ 3,3dimethyl-2-oxobutanoate $\mathrm{kg} \mathrm{Mg}^{-1} \mathrm{ww}$} & - & $0.19 \mathrm{e}^{-3}$ & - & - \\
\hline Sulphuric acid & $\mathrm{kg} \mathrm{Mg}^{-1} \mathrm{ww}$ & - & $0.19 \mathrm{e}^{-3}$ & - & - \\
\hline \multicolumn{6}{|c|}{$\begin{array}{l}{ }^{*} \text { composted digestate } \\
{ }^{* *} \text { adjusted after Davidsson et al. (2007) } \\
{ }^{* * *} \text { provision + combustion } \\
{ }^{* * * *} \text { based on Egglestone et al. (2006) and Chung (2007) }\end{array}$} \\
\hline
\end{tabular}


- One stage "wet" thermophilic anaerobic digestion plant (T3) for treatment of sourceseparated organic waste (kitchen waste, garden waste, organic waste from restaurants, green markets, food stores, etc) and production of biogas and digestate used as a fertilizer at farms. In the one stage process, the initial hydrolysis and acidification takes place in the same reactor vessel as the methane production. The wet process has moisture content above $90 \%$. The digestion temperature is typically around $53-55{ }^{\circ} \mathrm{C}$ for thermophilic digestion. Included in data-set are energy use for heating the reactor to thermophilic temperature, diesel to operate machinery at the plant and electricity for pumps, mixers etc. The data-set is constructed from measured data from a number of European biogas plants (none of the plants could provide data for all the parameters necessary to model the process) and thus represent a hypothetical average digestion plant developed in Western Europe, as described in Møller et al. (2010).

- Combined anaerobic-aerobic reactor (T4) for treatment of source-separated organic waste (kitchen waste and garden waste as structure material) and production of biogas and compost suitable for agricultural, horticultural and gardening purposes. The plant consists of a reception facility and a number of $600 \mathrm{~m}^{3}$ process modules. The treatment is initiated by mixing the source-separated organic waste with structure material in the form of shredded garden/park waste. The mixture is placed in the process modules under anaerobic conditions and water is sprinkled on top of the material. Hydrolyses and fermentation processes result in organic acid formation. The percolate containing organic acids is pumped to a process tank for methane production. The process can thus be classified as two-step anaerobic biogas production with acid formation and methanogenesis taking place in separate compartments. After biogas production has levelled off, the process modules are turned aerobic by suction of air through the material. Thereby a rapid composting process is initiated. The exhaust air from the composting process is treated in a biofilter. After biogas production and subsequent composting in the closed reactor modules the compost is placed in open windrows for maturation. The dataset is developed mostly using data supplied by a Danish facility, integrated with literature data as specified in Table 2.

\subsection{Assumptions}

A technological assessment of the four technologies from an environmental perspective was carried out. Similar assumptions were made to make the comparison transparent:

- One Mg of source-separated organic waste consisting of $2 / 3$ vegetable food waste and $1 / 3$ garden waste was used as input waste for the comparison. Physical-chemical characteristics of waste are reported in Table 3.

- Collection/transportation of waste is not included in the comparison.

- The input electricity mix was the same in all four cases (coal).

- The produced compost/digestate is supposed to be used on agricultural arable land. The modelling is performed according to Hansen et al. (2006), assuming loamy soil located in the Eastern part of Denmark. Modelling parameters are reported in Table 4, according to Bruun et al. (2006). The application of biotreated waste is modelled in EASEWASTE as a function of the compost/digestate composition, crop rotation and the local soil properties. The use-onland module in EASEWASTE includes a thorough modelling of the uptake and degradation of nutrients, formation of different gaseous emissions, leaching and runoff of pollutants, contamination of soil with heavy metals, and carbon sequestration.

- Biogas produced during anaerobic digestion is treated in a gas engine (see details in Table 5), where energy is recovered in form of electricity and heat. Electricity is delivered to the 
electricity grid, while heat is delivered into the local district heating network. The marginal technologies for energy production are assumed to be coal for electricity and the average Danish district heating for the heat.

- The LCls do not include eventual leaching during the process, land use for establishment of facilities, or water usage during different processes.

- Additional benefits from application of compost on land - increased water retention of the soil (reduced irrigation), reduced herbicide/biocide requirement, improved soil structure, and reduced erosion (Boldrin et al., 2009) - are not included.

Table 3 - Composition of input waste fractions and green waste ( $2 / 3$ vegetable food $+1 / 3$ garden waste) used in the comparison.

\begin{tabular}{|c|c|c|c|c|}
\hline Parameter & Unit & Vegetable food waste & Garden waste & Green waste \\
\hline TS & $\% w w$ & 23.0 & 51.8 & 32.6 \\
\hline VS & $\%$ TS & 94.8 & 76.0 & 84.8 \\
\hline Ash & $\%$ TS & 5.2 & 24.0 & 15.1 \\
\hline C-tot & $\%$ TS & 47.7 & 43.0 & 45.2 \\
\hline H & $\%$ TS & 6.6 & 5.2 & 5.9 \\
\hline 0 & $\%$ TS & 39.4 & 25.9 & 32.2 \\
\hline $\mathbf{N}$ & $\%$ TS & 1.9 & 1.5 & 1.7 \\
\hline $\mathbf{P}$ & $\% \mathrm{TS}$ & 0.23 & 0.20 & 0.21 \\
\hline K & $\%$ TS & 1.27 & 1.27 & 1.27 \\
\hline $\mathbf{S}$ & $\mathrm{Mg} \mathrm{kg}^{-1} \mathrm{TS}$ & 1840 & 1900 & 1872 \\
\hline Al & $\mathrm{Mg} \mathrm{kg}^{-1} \mathrm{TS}$ & 1030 & 2360 & 1734 \\
\hline $\mathrm{Fe}$ & $\mathrm{Mg} \mathrm{kg}^{-1} \mathrm{TS}$ & 310 & 1480 & 930 \\
\hline $\mathrm{Ca}$ & $\mathrm{Mg} \mathrm{kg}^{-1} \mathrm{TS}$ & 5550 & 21100 & 13784 \\
\hline $\mathrm{Na}$ & $\mathrm{Mg} \mathrm{kg}^{-1} \mathrm{TS}$ & 3120 & 944 & 1968 \\
\hline Mg & $\mathrm{Mg} \mathrm{kg}^{-1} \mathrm{TS}$ & 1210 & 1900 & 1575 \\
\hline $\mathbf{F}$ & $\mathrm{Mg} \mathrm{kg}^{-1} \mathrm{TS}$ & 100 & 100 & 100 \\
\hline $\mathrm{Cl}$ & $\mathrm{Mg} \mathrm{kg}^{-1} \mathrm{TS}$ & 5600 & 2800 & 4117 \\
\hline As & $\mathrm{Mg} \mathrm{kg}^{-1} \mathrm{TS}$ & 0.26 & 0.94 & 0.62 \\
\hline Cd & $\mathrm{Mg} \mathrm{kg}^{-1} \mathrm{TS}$ & 0.09 & 0.36 & 0.23 \\
\hline $\mathrm{Cr}$ & $\mathrm{Mg} \mathrm{kg}^{-1} \mathrm{TS}$ & 5.2 & 4.5 & 4.8 \\
\hline $\mathrm{Cu}$ & $\mathrm{Mg} \mathrm{kg}^{-1} \mathrm{TS}$ & 12.5 & 20.2 & 16.6 \\
\hline $\mathrm{Hg}$ & $\mathrm{Mg} \mathrm{kg}^{-1} \mathrm{TS}$ & 0.02 & 0.26 & 0.15 \\
\hline$M n$ & $\mathrm{Mg} \mathrm{kg}^{-1} \mathrm{TS}$ & 86 & 115 & 101 \\
\hline Mo & $\mathrm{Mg} \mathrm{kg}^{-1} \mathrm{TS}$ & 0.87 & 1.20 & 1.05 \\
\hline $\mathrm{Ni}$ & $\mathrm{Mg} \mathrm{kg}^{-1} \mathrm{TS}$ & 2.6 & 3.2 & 2.9 \\
\hline $\mathrm{Pb}$ & $\mathrm{Mg} \mathrm{kg}^{-1} \mathrm{TS}$ & 1.0 & 24.4 & 13.4 \\
\hline $\mathrm{Zn}$ & $\mathrm{Mg} \mathrm{kg}^{-1} \mathrm{TS}$ & 25 & 208 & 122 \\
\hline LHV & MJ kg-1TS & 18.3 & 13.4 & 15.7 \\
\hline $\mathrm{CH}_{4-\text { pot }}$ & $\mathrm{m}^{3} \mathrm{CH}_{4} \mathrm{Mg}^{-1} \mathrm{TS}$ & 450 & 100 & 265 \\
\hline
\end{tabular}


Table 4 - Modelling parameters for use-on-land of compost/digestate, after Brunn et al. (2006).

\begin{tabular}{|c|c|c|c|}
\hline Soil type & Unit & $\begin{array}{c}\text { Compost } \\
100 \% \text { loamy }\end{array}$ & $\begin{array}{c}\text { Digestate } \\
100 \% \text { loamy }\end{array}$ \\
\hline \multicolumn{4}{|l|}{ Emissions } \\
\hline $\mathrm{NO}_{3}-\mathrm{N}$ runoff & $\%$ applied $\mathrm{N}$ & 20 & 25 \\
\hline $\mathrm{NO}_{3}-\mathrm{N}$ leaching & $\%$ applied $\mathrm{N}$ & 20 & 22 \\
\hline $\mathrm{NH}_{3}-\mathrm{N}$ content & $\%$ total $\mathrm{N}$ & 13 & 13 \\
\hline $\mathrm{NH}_{3}$ evaporation & $\%$ of $\mathrm{NH}_{3}$ & 1.6 & 7.5 \\
\hline $\mathrm{N}_{2} \mathrm{O}$ formation & $\%$ total $\mathrm{N}$ & 1.5 & 1.4 \\
\hline C binding & $\%$ total C & 14 & 13 \\
\hline \multicolumn{4}{|c|}{ Substitution of fertilizer } \\
\hline $\mathbf{N}$ fertilizer & $\%$ applied $\mathrm{N}$ & 20 & 40 \\
\hline P fertilizer & $\%$ applied $\mathrm{P}$ & 100 & 100 \\
\hline K fertilizer & $\%$ applied $\mathrm{K}$ & 100 & 100 \\
\hline
\end{tabular}

Table 5 - Biogas utilization modelling parameters.

\begin{tabular}{lcc}
\hline Parameter & \multicolumn{1}{c}{ Unit } & Amount \\
\hline $\begin{array}{ll}\text { Energy recovery } \\
\text { Electricity }\end{array}$ & \% energy input \\
Heat & \% energy input & 39.1 \\
\hline \multicolumn{2}{l}{ Process specific emissions } & 46.3 \\
\hline $\mathrm{NO}_{\mathbf{x}}$ & $\mathrm{g} \mathrm{Nm}^{-3} \mathrm{CH}_{4}$ & 0.79 \\
$\mathrm{~N}_{\mathbf{2}} \mathrm{O}$ & $\mathrm{g} \mathrm{Nm}^{-3} \mathrm{CH}_{4}$ & 0.02 \\
$\mathrm{SO}_{2}$ & $\mathrm{~g} \mathrm{~N} \mathrm{~m}^{-3} \mathrm{CH}_{4}$ & 0.55 \\
$\mathrm{CO}$ & $\mathrm{g} \mathrm{N} \mathrm{m}^{-3} \mathrm{CH}_{4}$ & 16.87 \\
\hline
\end{tabular}

\subsection{Impact assessment}

Impact assessment was carried out for some of the non-toxic impact categories based on the EDIP97 method (Wenzel et al., 1997; further updates by Stranddorf et al., 2005). Results are presented as normalised potential impacts - based on normalization reference reported in Table 6 - and expressed as Person Equivalent (PE), which is the contribution to the given impact category of an average citizen. The time horizon of the assessment was 100 years, which was particularly important for binding of carbon to soil.

Results for toxic categories were excluded from the present study. Potential toxic impacts rising after application of compost/digestate on land are due to heavy metals contained in the waste (Boldrin et al., 2010). Thus, since a unique waste composition was assumed for the comparison and the majority of the heavy metals would remain with the dry matter being used on land, the results for toxic categories would be very similar for the different alternatives compared.

Results of the comparison are shown in Figure 1, where the normalized potential impacts from the biological process of waste are disaggregated from the potential impacts from the downstream processes (use-on-land of compost/digestate and use of biogas). Clear differences between the analysed technologies can be seen, both at the process level and further use-on-land of the composted/digested material.

Tunnel composting performs in this case better than windrow composting - in global warming, acidification, and nutrient enrichment categories - because of lower electricity 
consumption and better gas cleaning, resulting in lower emissions of $\mathrm{CO}_{2}$-fossil, $\mathrm{CH}_{4}$ and $\mathrm{N}_{2} \mathrm{O}$ (contribution to global warming) and $\mathrm{NH}_{3}$ (contributing to acidification and nutrient enrichment). The electricity consumption may vary significantly among plants and may also be higher for tunnel composting plants than for windrow composting plants. It must be noted that, according to the used literature, the $\mathrm{LCl}$ for the windrow composting technology does not include emissions of $\mathrm{CH}_{4}$, despite the fact that $\mathrm{CH}_{4}$ emissions are reported to occur even in well aerated composting systems (Boldrin et al., 2009). Energy recovery by means of anaerobic digestion has some benefits in most of the categories. The production of heat and electricity utilizing biogas offsets production of energy (marginal: coal) elsewhere in the system. Thereby, both technologies including anaerobic digestion show negative (saved) potential impacts in global warming category - saved $\mathrm{CO}_{2}$-fossil and $\mathrm{CH}_{4}$ emissions. Benefits in acidification and nutrient enrichment categories are mainly due to saved $\mathrm{NO}_{\mathrm{x}}$ emissions from avoided coal-based electricity production.

Potential impacts occurring during use-on-land of compost/digestate are in most cases similar for the different technologies and roughly in the same order of magnitude as the direct impacts from the biological treatment process. However, in case of digestate application on land the potential impact on nutrient enrichment category is much bigger than for the other technologies. This is explainable with the fact that application of liquid digestate is possibly resulting in larger leaching of $\mathrm{NO}_{3}$ than application of solid compost. Savings from the application of compost/digestate in the global warming category are due to both saved production of mineral fertilizers and carbon binding to soil.

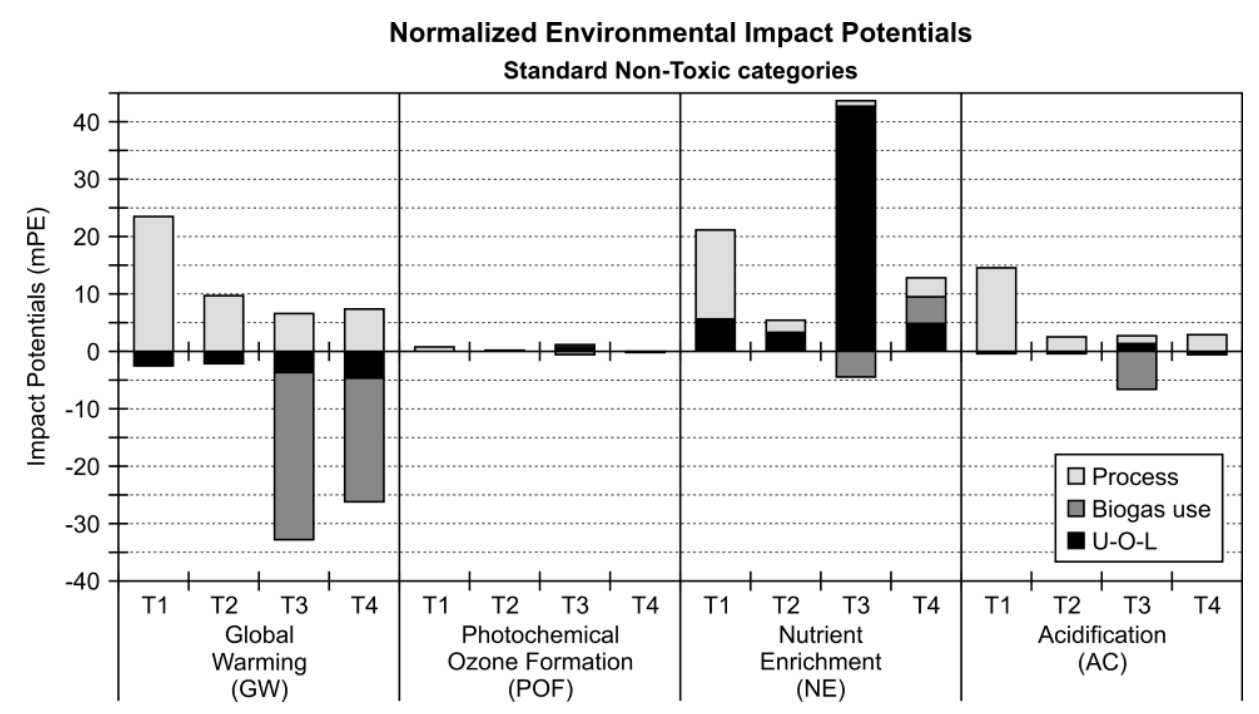

Figure 1 - Normalized potential non-toxic impacts from treatment of $1 \mathrm{Mg}$ of green waste (2/3 kitchen waste and $1 / 3$ garden waste) by means of the four treatment options. $\mathrm{PE}=$ person equivalent, $\mathrm{T} 1=$ windrow composting, $\mathrm{T} 2=$ tunnel composting, $\mathrm{T} 3=$ one stage anaerobic digestion, $\mathrm{T} 4=$ combined anaerobic digestion and composting. U-O-L: Use-on-land. 
Table 6 - Normalisation references for selected environmental impact categories in EDIP97 (Stranddorf et al., 2005).

\begin{tabular}{lccc}
\hline Impact category & $\begin{array}{c}\text { Geographical } \\
\text { scale }\end{array}$ & $\begin{array}{c}\text { Characterisation- } \\
\text { unit }\end{array}$ & $\begin{array}{c}\text { Normalization } \\
\text { reference } \\
\text { [Characterisation-unit } \\
\text { person }{ }^{-1} \text { year }^{-1} \text { ] }\end{array}$ \\
\hline Global warming (GW) & Global & $\mathrm{kg} \mathrm{CO}_{2}$-equivalents & $8.7 \cdot 10^{3}$ \\
Acidification (AC) & Regional & $\mathrm{kg} \mathrm{SO}_{2}$-equivalents & $7.4 \cdot 10^{1}$ \\
Nutrient enrichment (NE) & Regional & $\mathrm{kg} \mathrm{NO}_{3}$-equivalents & $1.2 \cdot 10^{2}$ \\
Photochemical ozone formation (POF) & Regional & $\mathrm{kg} \mathrm{C}_{2} \mathrm{H}_{4}$-equivalents & $2.5 \cdot 10^{1}$ \\
\hline
\end{tabular}

\section{Discussion and conclusion}

The described module for biological treatment of organic waste enables the user to estimate potential environmental effects from anaerobic digestion, composting, the combination of the two processes, and also MBT facilities. The module does not model the actual biological process, but performs a detailed mass balance for the organic waste. The materials in the waste are partly degraded and distributed between treated organic waste and residues. Emissions to air, water and soil are calculated from the composition of the waste fed to the plant and the key parameters characterizing the technology and operation of the plant. The use of these parameters make the biological treatment module flexible, allowing a large degree of case-specific data to be included. This is important, since biological treatment cover a broad variety of waste fractions and technologies. The necessary case-specific input data should be obtainable through direct measurements at the actual plants or alternatively through literature. Data examples from existing biological treatment plants are available in the module. However, since the variations on many of the parameters are large, data for one technology may not be valid for another.

The illustrative example showed that the EASEWASTE model can differentiate potential environmental impacts generated by alternative treatment options due to their specific technological features. Direct emissions of greenhouse gases and energy consumption during the biological process can be significant for the environmental footprint of the waste system. The examples also showed the importance of including downstream processes, even when performing technological assessments. In fact, the recovery of energy seems to have - from a system perspective - some benefits in terms of global warming emissions. Conversely, the type and quality of material produced during the biological process can have in some cases large influence on the overall results, thereby evidencing the need for a complex modelling of the compost/digestate application on land, including nutrient dynamics and emissions. However, the results presented are purely illustrative and decision-oriented LCA studies should make use of case-specific data and should include other part of the waste system excluded in the illustrative examples. 


\section{References:}

Andersen, J.K., Boldrin, A., Christensen, T.H., Scheutz, C., 2010. Mass balances and life-cycle inventory for a garden waste windrow composting plant (Aarhus, Denmark). Waste Management \& Research, doi:10.1177/0734242X09360216.

Boldrin, A., Andersen, J.K., Møller, J., Favoino, E., Christensen, T.H., 2009. Composting and compost utilization: Accounting of greenhouse gases and global warming contributions. Waste Management \& Research, 27, 800-812.

Boldrin, A., Hartling, K.R., Laugen, M., Christensen, T.H., 2010. Environmental inventory modelling of the use of compost and peat in growth media preparation. Revised for Resource, Conservation and Recycling.

Bruun, S., Hansen, T.L., Christensen, T.H., Magid, J., Jensen, L.S., 2006. Application of processed organic municipal solid waste on agricultural land: a scenario analysis. Environmental Modelling and Assessment, 11, 251-265.

Christensen, T.H., Bhander, G.S., Lindvall, H.K., Larsen, A.W., Fruergaard, T.H., Damgaard, A., Manfredi, S., Boldrin, A., Riber, C., Hauschild, M.Z., 2007. Experience with the use of LCAmodelling (EASEWASTE) in waste management. Waste Management \& Research, 25, 257262.

Chung, Y-C., 2007. Evaluation of gas removal and bacterial community diversity in a biofilter developed to treat composting exhaust gases. Journal of Hazardous Materials 144: 377385.

Dalemo, M., 1999. Environmental system analysis of organic waste management: The ORWARE model and the sewage plant and anaerobic digestion submodels. Agraria 146, Swedish University of Agricultural Sciences, Sweden.

Dalemo, M., Frostell, B., Jönsson, H., Mingarini, K., Nybrant, T., Sonesson, U., 1997. ORWARE - a simulation model for organic waste handling systems, Part 1: Model description. Resources, Conservation and Recycling, 21, 17-37.

Davidsson, S.A., Gruvberger, C., Christensen, T.H., Hansen, T.L., Jansen, J.L.C., 2007. Methane yield in source-sorted organic fraction of municipal solid waste. Waste Management 27, 406-414.

Den Boer, E., Den Boer, J. \& Jager, J., 2007. LCA-IWM: A decision support tool for sustainability assessment of waste management systems. Waste Management, 27, 1032-1045.

Den Boer, E., Den Boer, J. and Jager, J., Rodrigo, J., Meneses, M., Castells, F., Schanne, L., 2005. Deliverable Report on D3.1 and D3.2: Environmental Sustainability Criteria and Indicators for waste management (Work Package 3): The Use of Life Cycle Assessment Tool for the Development of Integrated Waste Management Strategies for Cities and Regions with Rapid Growing Economies LCA-IWM. 198 pp.

ECN, 2009. Personal communication with Josef Barth, managing director, European Compost Network (ECN).

Eggleston, S., Buendia, L., Miwa, K., Ngara, T., Tanabe, K., 2006. IPCC Guidelines for National Greenhouse Gas Inventories. Vol. 5 Waste. IPCC National Greenhouse Gas Inventories 
Programme, Institute for Global Environmental Strategies, Hayama, Kanagawa, Japan. Last accessed February 2010 at: http://www.ipcc-nggip.iges.or.jp/public/2006gl/vol5.html

Gentil, E.C., Damgaard, A., Hauschild, M., Finnveden, G., Eriksson, O., Thorneloe, S., Kaplan, P.O., Barlaz, M., Muller, O., Matsui, Y., Ii, R., Christensen, T.H., 2010. Models for waste life cycle assessment: Review of technical assumptions. Waste Management (2010), doi:10.1016/j.wasman.2010.06.004

Ham, R.K., Komilis, D.P., 2000. Life cycle inventory and cost model for mixed municipal and yard waste composting. EPA/R-99/XXX, United States Environmental Protection Agency, Washington, July 2000. Last accessed 22th February 2010 at: https://webdstmsw.rti.org/docs/Compost_Model_OCR.pdf

Ham, R.K., Komilis, D.P., 2003. A laboratory study to investigate gaseous emissions and solids decomposition during composting of municipal solid waste. EPA-600/R-03/004, United States Environmental Protection Agency, Washington, July 2000. Last accessed 22th February 2010 at: http://www.epa.gov/nrmrl/pubs/600r03004/600r03004.pdf

Hansen, T.L., Bhander, G.S., Christensen, T.H., Bruun, S., Jensen, L.S., 2006. Life cycle modelling of environmental impacts of application of processed organic municipal solid waste on agricultural land (EASEWASTE). Waste Management \& Research, 24, 153.

IEA, 2008. International Energy Agency Task 37: Energy from Biogas and Landfill Gas. Available online at http://www.iea-biogas.net.

International Standards Organisation (ISO), 2006. ISO 14040, Environmental Management Life Cycle Assessment - Principles and Framework. International Standards Organisation, Geneva, Switzerland. Reference Number ISO 14040:2006(E).

Kirkeby, J.T., Hansen, T.L., Birgisdóttir, H., Bhander, G.S., Hauschild, M.Z., Christensen, T.H., 2006. Environmental assessment of solid waste systems and technologies: EASEWASTE. Waste Management \& Research, 24, 3-15.

Komilis, D.P., Ham, R.K., 2004. Life-cycle inventory of municipal solid waste and yard waste windrow composting in the United States. Journal of Environmental Engineering, 130 (11), 2004.

McDougall, F., White, P., Franke, M., Hindle, P., 2001. Integrated solid waste management: A life cycle inventory. Procter \& Gamble Technical Centres Limited, Blackwell Science Ltd, UK.

Møller, J., Jansen, J.L.C., Christensen, T.H., 2010. Digestion: Mass balances and products. In: Christensen, T.H. (ed.) Solid Waste Management and Technologies. Wiley \& Sons, London.

Stranddorf, H.K., Hoffmann, L., Schmidt, A., 2005. Impact categories, normalisation and weighting in LCA, Updated on selected EDIP97-data. Environmental News No. 782005. Danish Environmental Protection Agency, Danish Ministry of the Environment, Copenhagen, Denmark.

The Ecobilan Group, 2004. WISARD Reference Guide. The Ecobilan Group.

Vogt, R., Knappe, F., Giegrich, J., Detzel, A., 2002. Ökobilanz Bioabfallverwertung, Untersuchungen zur Umweltverträglichkeit von Systemen zur Verwertung von biologish- 
organischen Abfallen. Ifeu, Institut für Energie- und Umweltforschung, Heidelberg GmbH, Erich Schmidt Verlag, Berlin, Germany.

Weitz, K.A., Barlaz, M.A., Ranjithan, S., Brill, E.D., Thorneloe, S.A., Ham, R., 1999. Life cycle management of municipal solid waste. International Journal of Life Cycle Assessment, 4, 195-201.

Wenzel, H., Hauschild, M., Alting, L., 1997. Environmental Assessment of Products, Vol. 1: Methodology, Tools and Case Studies in Product Development. Kluwer Academic Publishers, Hingham, MA, USA, 1997. 